\title{
Psychrophilic pseudomonads from Antarctica: Pseudomonas antarctica sp. nov., Pseudomonas meridiana sp. nov. and Pseudomonas proteolytica sp. nov.
}

Correspondence Sisinthy Shivaji shivas@ccmb.res.in

\author{
Gundlapalli S. N. Reddy, ${ }^{1}$ Genki I. Matsumoto, ${ }^{2}$ Peter Schumann, ${ }^{3}$ \\ Erko Stackebrandt ${ }^{3}$ and Sisinthy Shivaji ${ }^{1}$ \\ ${ }^{1}$ Centre for Cellular and Molecular Biology, Uppal Road, Hyderabad - 500 007, India \\ ${ }^{2}$ Department of Environmental and Information Science, Otsuma Women's University, Tamashi, \\ Tokyo 206, Japan
}

${ }^{3} \mathrm{DSMZ}$ - Deutsche Sammlung von Mikroorganismen und Zellkulturen GmbH, Mascheroder Weg 1b, D-38124 Braunschweig, Germany
The genus Pseudomonas was originally created by Migula (1894). Over the years, the genus has been redefined to differentiate it from other genera (Stanier et al., 1966; Palleroni et al., 1973; De Ley, 1992; Anzai et al., 2000). Moore et al. (1996) further delineated the genus Pseudomonas into two major intrageneric clusters, namely the Pseudomonas aeruginosa and Pseudomonas fluorescens clusters. Subsequently, based on phylogenetic analysis of 56 species of Pseudomonas sensu stricto, using 1063 bp of the 16S rRNA gene sequence, the genus was categorized into two main clusters (Anzai et al., 2000). The first cluster had six groups within it and these were designated as the

Published online ahead of print on 14 November 2003 as DOI 10.1099/ijs.0.02827-0.

The GenBank/EMBL/DDBJ accession numbers for the 16S rDNA sequences of strains CMS $35^{\top}, \mathrm{CMS} 38^{\top}$ and $\mathrm{CMS} 64^{\top}$ are AJ537601, AJ537602 and AJ537603, respectively.

Tables showing the fatty acid composition of and DNA-DNA relatedness data for the novel pseudomonads are available as supplementary material in IJSEM Online.
Pseudomonas syringae group (with 12 species), the Pseudomonas chlororaphis group (with five species), the P. fluorescens group (with 18 species), the Pseudomonas putida group (with six species), the $P$. aeruginosa group (with 11 species) and the Pseudomonas stutzeri group (with three species). The second cluster had only one group, the Pseudomonas pertucinogena group, which contained two species.

Until now, about 100 species of the genus Pseudomonas have been reported from various habitats, including Antarctica. Kriss et al. (1976) were the first to report the existence of Pseudomonas species in Antarctica. However, they were not identified at species level until 1989, when Pseudomonas spp. isolated from Antarctic soil and water samples were identified as psychrophilic strains of $P$. aeruginosa, $P$. fluorescens, $P$. putida and $P$. syringae (Shivaji et al., 1989a). More recently, Maugeri et al. (1996) and Bruni et al. (1999) isolated bacteria that belonged to the genus Pseudomonas from sea water and freshwater samples from Terra Nova Bay and Wanda Lake, Antarctica. However, these were also not characterized at species level. In the present study, attempts were made to identify bacteria that 
belong to the genus Pseudomonas that were isolated from cyanobacterial mat samples collected from the McMurdo region, Antarctica.

\section{Source of the organisms, media and growth conditions}

Thirty-one bacterial isolates were obtained from cyanobacterial mat that were samples collected from ponds L1 (strains CMS 62-72) and L3 (CMS 33-36) of Wright Valley, Adam's glacier stream 1 (CMS 43-50), Adam's glacier stream 2 (CMS 37, CMS $38^{\mathrm{T}}$ and CMS 40) and Canada glacier stream (CMS 41-42) of Miers Valley and Lake Canopus (CMS 54, CMS 57 and CMS 60) in Antarctica. Pure cultures of the heterotrophic bacteria were set up as described previously (Reddy et al., 2000). Optimum temperature, $\mathrm{pH}$ and salt concentration for growth of cultures were determined by using plates of Antarctic bacterial medium $(\mathrm{ABM})$ that contained $0.5 \%(\mathrm{w} / \mathrm{v})$ peptone, $0.2 \%$ $(\mathrm{w} / \mathrm{v})$ yeast extract and $1.5 \%(\mathrm{w} / \mathrm{v})$ agar $(\mathrm{pH} 6.9)$ (Reddy et al., 2002, 2003).

\section{Morphology, motility and biochemical characteristics}

Bacterial cultures in the lag, exponential and stationary phases of growth were observed under a phase-contrast microscope $(\times 1000)$ to ascertain their shape and motility. All biochemical tests were performed by growing cultures at $22^{\circ} \mathrm{C}$ in appropriate medium (Hugh \& Leifson, 1953; Stanier et al., 1966; Holding \& Collee, 1971; Stolp \& Gadkari, 1981). Furthermore, ability of the cultures to utilize a carbon compound as sole carbon source, sensitivity to different antibiotics and DNA G $+\mathrm{C}$ contents were determined as described previously (Shivaji et al., 1989b). Total protein profiles of the cultures were determined by SDS-PAGE. For this purpose, cultures were grown in $3 \mathrm{ml} \mathrm{ABM}$ broth at $25^{\circ} \mathrm{C}$ and harvested at 6000 r.p.m. for $10 \mathrm{~min}$ at room temperature; the pellets were resuspended in $100 \mu \mathrm{l}$ water and $100 \mu \mathrm{l} \mathrm{SDS/sample} \mathrm{buffer.} \mathrm{The} \mathrm{sus-}$ pension was then boiled for $5 \mathrm{~min}$ and centrifuged at 10000 r.p.m. for $10 \mathrm{~min}$; $50 \mu \mathrm{l}$ supernatant was loaded onto $12 \%$ SDS/polyacrylamide gel (Laemmli, 1970). Bands were visualized by staining with Coomassie blue.

\section{DNA-DNA hybridization and identification of fatty acids}

DNA-DNA hybridization was performed by the membrane filter method (Tourova \& Antonov, 1987) as described previously (Shivaji et al., 1992; Reddy et al., 2000). Fatty acids were identified from bacterial cell pellets by comparison with fatty acid standards that were run under similar GC conditions and also by mass spectrometry (Sato \& Murata, 1988; Reddy et al., 2003).

\section{Riboprinting}

A pure colony of each of strains CMS $35^{\mathrm{T}}$, CMS $38^{\mathrm{T}}$ and CMS $64^{\mathrm{T}}$ and Pseudomonas brenneri was picked up with a sterile toothpick and suspended in a $1.5 \mathrm{ml}$ microfuge tube that contained $200 \mu \mathrm{l}$ riboprinting buffer (DuPont Qualicon). The tube was then heated to $70{ }^{\circ} \mathrm{C}$ for $10 \mathrm{~min}$ in a model 480 DNA thermocycler (Perkin Elmer) and the contents were transferred to a sample carrier (DuPont Qualicon). Lysis reagent A and reagent B (5 $\mu \mathrm{l}$ each) were added before inserting the sample carrier into the characterization unit of the Qualicon Riboprinter system, where the samples were processed automatically according to the EcoRI standard protocol.

\section{$16 S$ rRNA gene sequencing}

Amplification of the 16S rRNA gene, purification of the $1.5 \mathrm{~kb}$ amplicon and sequencing of the amplicon were carried out by the method of Lane (1991), as described previously (Shivaji et al., 2000).

\section{Phylogenetic analysis}

$16 \mathrm{~S}$ rRNA gene sequences of the three bacteria that represented the 31 isolates were aligned with reference sequences of all species in the $P$. fluorescens group (obtained from GenBank/EMBL) by using the multiple sequence alignment program CLUSTAL V (Higgins et al., 1992). The aligned sequences were then checked manually for gaps. The DNADIST program was used to compute pairwise evolutionary distances for the aligned sequences by applying the Kimura two-parameter model (Kimura, 1980). Furthermore, the original sequence dataset was resampled 1000 times by using SEQBOOT and subjected to bootstrap analysis to obtain confidence values for $16 \mathrm{~S}$ rRNA gene sequencebased genetic affiliations. The multiple distance matrices thus obtained were used to construct phylogenetic trees by using various distance matrix-based clustering algorithms, such as FITCH, KITSCH and UPGMA, as compiled in the Phylogeny Inference Package (PHYLIP; Felsenstein, 1993). Parsimony analysis was also performed for the aligned sequence dataset by using DNAPARS. In all cases, the input order of species added to the topology being constructed was randomized by using the jumble option with a random seed of 7 and ten replications. Majority-rule (50\%) consensus trees were constructed for the topologies by using CONSENSE. All these analyses were done by using the PHYLIP package, version 3.5c (Felsenstein, 1993).

\section{Reference strains}

P. brenneri CIP $106646^{\mathrm{T}}$, Pseudomonas orientalis CIP $105540^{\mathrm{T}}$, Pseudomonas veronii CIP $104663^{\mathrm{T}}$, Pseudomonas marginalis ATCC $10844^{\mathrm{T}}$, Pseudomonas rhodesiae CIP $104664^{\mathrm{T}}$, Pseudomonas tolaasii ATCC $33618^{\mathrm{T}}$, Pseudomonas migulae CIP $105470^{\mathrm{T}}$ and P. fluorescens ATCC $13525^{\mathrm{T}}$ were used as controls in studies that were related to the identification of fatty acids and DNA-DNA hybridization.

\section{Conclusions}

Thirty-one individual bacterial colonies were isolated from cyanobacterial mat samples that were collected from various 
water bodies in Antarctica. These 31 isolates could be categorized into three groups, based on their protein profiles as analysed by SDS-PAGE (data not shown), namely group I (CMS 33-36 and CMS 44-50), group II (CMS $38^{\mathrm{T}}$ ) and group III (CMS 37, CMS 40-41, CMS 43, CMS 54, CMS 57, CMS 60 and CMS 62-72). Members of the same group exhibited identical protein profiles, indicating that they are probably clonal in origin. Therefore, strains CMS $35^{\mathrm{T}}$, CMS $38^{\mathrm{T}}$ and CMS $64^{\mathrm{T}}$ were chosen as representative isolates of groups I, II and III, respectively.

These three isolates, namely CMS $35^{\mathrm{T}}$, CMS $38^{\mathrm{T}}$ and CMS $64^{\mathrm{T}}$, are aerobic, Gram-negative, rod-shaped and motile, possess a polar flagellum and have $\mathrm{C}_{16: 0}, \mathrm{C}_{16: 1} \omega 7 c$, $\mathrm{C}_{16: 1} \omega 9 c$ and $\mathrm{C}_{18: 1}$ as their major fatty acids, indicating their affiliation to the genus Pseudomonas. They could all grow at $4-30{ }^{\circ} \mathrm{C}$ and did not accumulate polyhydroxybutyric acid. Riboprinting analysis indicated that strains CMS $35^{\mathrm{T}}$, CMS $38^{\mathrm{T}}$ and CMS $64^{\mathrm{T}}$ are distinctly different from each other (Tables 1 and 2; Supplementary Table A, available in IJSEM Online; Fig. 1).

Phylogenetic analysis of the three isolates, based on $1438 \mathrm{bp}$ of the 16S rRNA gene sequence, indicated a close relationship with species that belong to the $P$. fluorescens group (Anzai et al., 2000) (Fig. 2). Evolutionary distances, as calculated by using the Kimura two-parameter model, indicated that the three isolates are related very closely to each other, with $>99 \% 16$ S rRNA gene sequence similarity, and also to other species of the P. fluorescens group (Anzai et al., 2000). At the DNA-DNA level, there was $40 \%$ relatedness between strains CMS $35^{\mathrm{T}}$ and CMS $38^{\mathrm{T}}, 40 \%$ between CMS $35^{\mathrm{T}}$ and CMS $64^{\mathrm{T}}$ and $43 \%$ between CMS $38^{\mathrm{T}}$ and CMS $64^{\mathrm{T}}$ (Supplementary Table B, available in IJSEM Online).

The topology of the tree indicates that strain CMS $64^{\mathrm{T}}$ is related phylogenetically to the clade that represents

Table 1. Phenotypic characteristics that differentiate strains $\mathrm{CMS} 35^{\top}$ ( $P$. antarctica) and $\mathrm{CMS} 38^{\top}$ ( $P$. meridiana) from each other and from closely related species of the genus Pseudomonas

Taxa: 1, CMS $35^{\mathrm{T}} ; 2$, CMS $38^{\mathrm{T}} ; 3$, P. orientalis [data from Dabboussi et al. (1999)]; 4, P. marginalis [data from Shinde \& Lukezic (1974) and Munsch et al. (2002)]; 5, P. rhodesiae [data from Coroler et al. (1996)]; 6, P. veronii [data from Elomari et al. (1996)]; 7, P. extremorientalis [data from Ivanova et al. (2002)]; 8, P. tolaasii [data from Ivanova et al. (2002)]; 9, P. costantinii [data from Munsch et al. (2002)]. +, Positive; - , negative; $(+)$, weakly positive; NA, data not available. All taxa are positive for the utilization of trehalose.

\begin{tabular}{|c|c|c|c|c|c|c|c|c|c|}
\hline Characteristic & 1 & 2 & 3 & 4 & 5 & 6 & 7 & 8 & 9 \\
\hline \multicolumn{10}{|l|}{ Temperature $\left({ }^{\circ} \mathrm{C}\right)$ : } \\
\hline Optimum & 22 & 22 & NA & NA & NA & NA & 25 & NA & NA \\
\hline \multicolumn{10}{|l|}{ Phenotypic characteristics } \\
\hline Phosphatase & + & - & + & NA & NA & NA & NA & $\mathrm{NA}$ & NA \\
\hline Urease & + & $(+)$ & + & NA & NA & $\mathrm{NA}$ & NA & NA & NA \\
\hline Gelatinase & - & - & NA & + & - & + & - & + & + \\
\hline Nitrate to nitrite reduction & + & + & + & + & NA & NA & + & - & - \\
\hline Production of fluorescent pigment on King's B medium & - & + & + & + & + & + & + & NA & + \\
\hline \multicolumn{10}{|l|}{ Utilization of carbon compounds } \\
\hline D-Galactose & + & + & + & + & + & + & + & - & + \\
\hline D-Glucose & + & + & + & NA & + & + & - & + & + \\
\hline Glycerol & + & + & NA & NA & NA & + & + & - & + \\
\hline meso-Inositol & + & + & + & + & + & + & - & + & + \\
\hline Lactose & - & - & - & NA & NA & - & - & + & - \\
\hline D-Maltose & - & - & - & NA & NA & + & + & + & - \\
\hline D-Mannitol & + & + & + & - & + & + & + & - & + \\
\hline D-Melibiose & - & - & - & NA & NA & - & - & + & - \\
\hline L-Rhamnose & - & - & NA & NA & - & - & - & + & - \\
\hline Sucrose & - & - & NA & + & + & + & + & + & + \\
\hline D-Xylose & - & - & + & + & + & + & + & + & + \\
\hline
\end{tabular}


Table 2. Phenotypic differences between strain CMS $64^{\top}$ ( $P$. proteolytica), $P$. brenneri and $P$. migulae

Taxa: 1, CMS $64^{\mathrm{T}}$; 2, P. brenneri [data from Baïda et al. (2001)]; 3, P. migulae [data from Verhille et al. (1999)]. +, Positive; -, negative; NA, data not available.

\begin{tabular}{|lccc|}
\hline Characteristic & $\mathbf{1}$ & $\mathbf{2}$ & $\mathbf{3}$ \\
\hline Growth characteristics & & & \\
Temperature range for growth $\left({ }^{\circ} \mathrm{C}\right)$ & $4-30$ & $4-37$ & $4-35$ \\
Optimum growth temperature $\left({ }^{\circ} \mathrm{C}\right)$ & 22 & 25 & 30 \\
Phenotypic characteristics & & & \\
Phosphatase & - & + & NA \\
Lipase & + & + & - \\
Gelatinase & + & + & - \\
Levan formation on sucrose & - & + & + \\
Utilization of carbon compounds & & & \\
Adonitol & + & + & - \\
L-Arabinose & - & - & + \\
Erythritol & + & + & - \\
Fumaric acid & - & - & + \\
meso-Inositol & + & + & - \\
L-Rhamnose & - & + & - \\
Sorbitol & + & - & - \\
D-Xylose & - & - & + \\
L-Aspartic acid & - & + & + \\
L-Proline & - & + & + \\
L-Tryptophan & + & - & - \\
& & & \\
\hline
\end{tabular}

P. brenneri (Baïda et al., 2001) and P. migulae (Verhille et al., 1999) (Fig. 2), with a bootstrap value of $86 \%$. The other two Antarctic isolates, CMS $35^{\mathrm{T}}$ and CMS $38^{\mathrm{T}}$ (Fig. 2), appear to be related more closely to $P$. orientalis (Dabboussi et al., 1999).

\section{Identification of strain CMS $35^{\top}$ as Pseudomonas antarctica sp. nov.}

Strain CMS $35^{\mathrm{T}}$ can be differentiated from strains CMS $38^{\mathrm{T}}$ and CMS $64^{\mathrm{T}}$ with respect to its protein profile, riboprint, phenotypic characteristics and low (40\%) DNADNA relatedness (Tables 1 and 2; Supplementary Table B, available in IJSEM Online; Fig. 1). Strain CMS $35^{\mathrm{T}}$ can also be differentiated easily from the closely related species $P$. orientalis (Dabboussi et al., 1999), P. marginalis, P. rhodesiae and $P$. veronii, based on phenotypic characteristics (Table 1) and the fact that it shows $<60 \%$ relatedness at the DNA-DNA level with these species. Therefore, strain CMS $35^{\mathrm{T}}$ is proposed as the type strain of a novel species of the genus Pseudomonas, to which the name Pseudomonas antarctica sp. nov. is assigned.

\section{Identification of strain CMS $38^{\top}$ as Pseudomonas meridiana sp. nov.}

Strain CMS $38^{\mathrm{T}}$, which is different from CMS $35^{\mathrm{T}}$ (Table 1 ), shares $99 \cdot 46 \% 16 \mathrm{~S}$ rRNA gene sequence similarity with $P$. orientalis (Fig. 2); however, it differs from P. orientalis
1

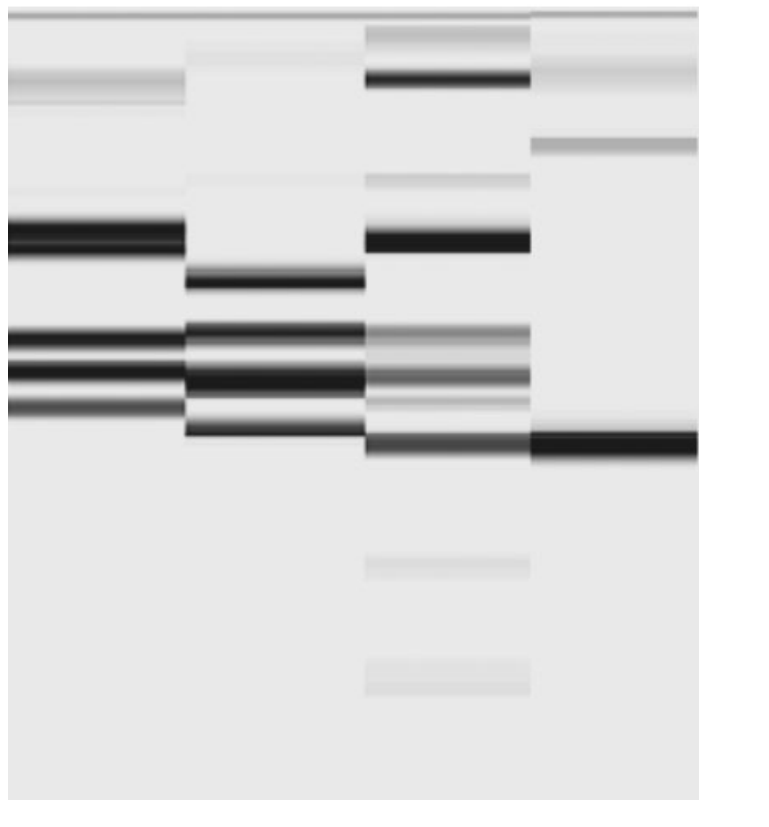

Fig. 1. Riboprinting of strains: $1, \mathrm{CMS} 38^{\mathrm{T}}$ (Pseudomonas meridiana); 2, CMS $35^{\top}$ (Pseudomonas antarctica); 3, CMS $64^{\top}$ (Pseudomonas proteolytica); 4, P. brenneri CIP $106646^{\top}$.

(Dabboussi et al., 1999) in a number of phenotypic traits (Table 1 ) and its protein profile and exhibits $64 \%$ relatedness at the DNA-DNA level (Supplementary Table B, available in IJSEM Online). In addition, strain CMS $38^{\mathrm{T}}$ exhibits 52, 58 and $49 \%$ DNA-DNA relatedness (Supplementary Table B, available in IJSEM Online) respectively with $P$. marginalis, $P$. rhodesiae and $P$. veronii, which are part of the main cluster of the phylogenetic tree (Fig. 2). DNA-DNA hybridization was not performed between strain CMS $38^{\mathrm{T}}$ and Pseudomonas extremorientalis (Ivanova et al., 2002), P. tolaasii (Bradbury, 1987) or Pseudomonas costantinii (Munsch et al., 2002), but they can be differentiated easily, based on phenotypic characteristics (Table 1). Thus, based on the above differences between strains CMS $38^{\mathrm{T}}$, CMS $35^{\mathrm{T}}$ and P. orientalis, CMS $38^{\mathrm{T}}$ is proposed as the type strain of a novel species of the genus Pseudomonas, to which the name Pseudomonas meridiana sp. nov. is assigned.

\section{Identification of strain CMS $64^{\top}$ as Pseudomonas proteolytica sp. nov.}

Strain CMS $64^{\mathrm{T}}$ can be differentiated from strains CMS $35^{\mathrm{T}}$ and CMS $38^{\mathrm{T}}$ by phenotypic characteristics (Tables 1 and 2). In addition, these isolates differ in their protein profiles, riboprints and DNA-DNA relatedness (Supplementary Table B, available in IJSEM Online; Fig. 1). At the $16 \mathrm{~S}$ rRNA gene sequence level, strain CMS $64^{\mathrm{T}}$ is related closely to P. brenneri $(99 \cdot 73 \%)$ and P. migulae $(99 \cdot 75 \%)$ (Fig. 2). Characteristics that differentiate strain CMS $64^{\mathrm{T}}$ from P. migulae (Verhille et al., 1999) and P. brenneri (Baïda et al., 2001) are listed in Table 2. Furthermore, strain CMS 


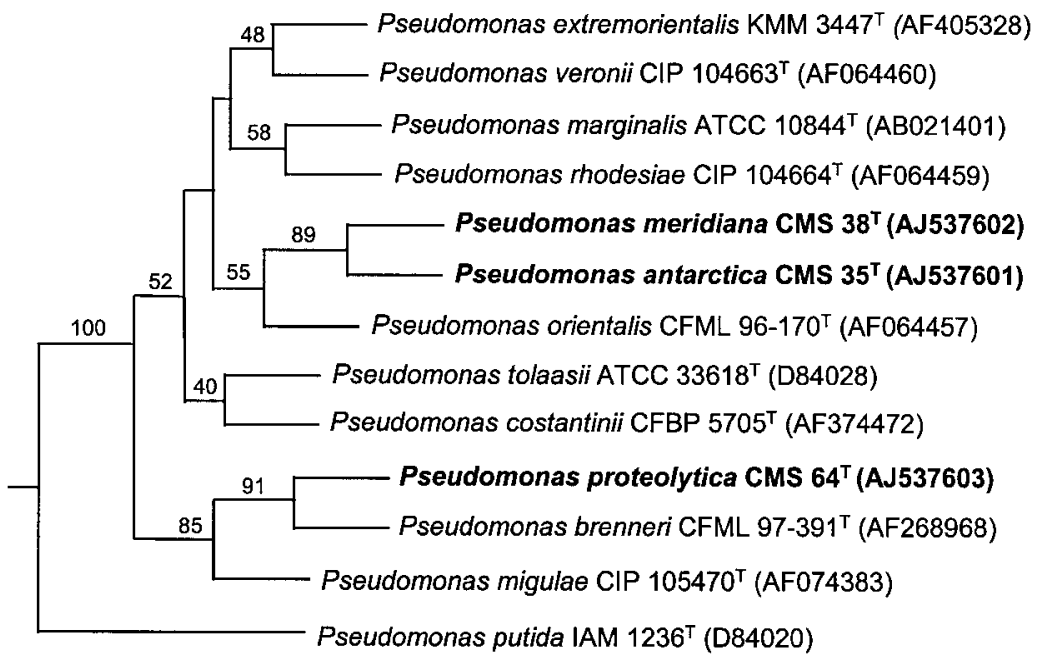

Fig. 2. UPGMA phenogram showing the phylogenetic relationship between the psychrophilic species $P$. antarctica (CMS $35^{\top}$ ), $P$. proteolytica (CMS $64^{\top}$ ) and $P$. meridiana $\left(\mathrm{CMS} 38^{\mathrm{T}}\right)$ and other related species of the genus Pseudomonas, based on 16S rDNA sequence analysis. Bootstrap values are given at nodes. Branch-lengths in the phenogram are not to scale.

$64^{\mathrm{T}}$ exhibits differences in protein profile and shows only $55 \%$ relatedness with $P$. migulae and $68 \%$ with $P$. brenneri at the DNA-DNA level (Supplementary Table B, available in IJSEM Online). The riboprint of strain CMS $64^{\mathrm{T}}$ is also different from that of P. brenneri (Fig. 1). Thus, based on phenotypic, genotypic and phylogenetic characteristics, strain CMS $64^{\mathrm{T}}$ is proposed as the type strain of a novel species of the genus Pseudomonas, to which the name Pseudomonas proteolytica sp. nov. is assigned.

\section{Description of Pseudomonas antarctica sp. nov.}

Pseudomonas antarctica (an.tarc'ti.ca. N.L. fem. adj. antarctica pertaining to Antarctica).

Forms circular, convex, smooth and translucent colonies with a diameter of 1-2 $\mathrm{mm}$. Cells are Gram-negative, motile with a polar flagellum, rod-shaped and psychrophilic (grow at $4-30{ }^{\circ} \mathrm{C}$ ), can tolerate $3 \% \mathrm{NaCl}(\mathrm{w} / \mathrm{v}$ ) and grow at an optimum $\mathrm{pH}$ of 7 . Positive for catalase, oxidase, urease and phosphatase and weakly positive for lipase; reduces nitrate to nitrite; negative for $\beta$-galactosidase, gelatinase, arginine dihydrolase, arginine decarboxylase, lysine decarboxylase, indole production, methyl red and Voges-Proskauer test. Does not hydrolyse aesculin, starch or cellulose. Acid is produced from D-fructose, D-galactose, D-glucose, D-mannose and D-mannitol, but not from L-arabinose, lactose, L-rhamnose, sucrose or D-xylose. Utilizes acetate, adonitol, citrate, meso-erythritol, D-fructose, D-galactose, D-glucose, glycerol, meso-inositol, lactic acid, D-mannose, D-mannitol, pyruvate, D-ribose, sorbitol, trehalose, Lalanine, L-arginine, L-glutamic acid, L-glutamine, L-lysine, L-serine, L-tyrosine and L-tryptophan as sole carbon sources, but not L-arabinose, D-cellobiose, cellulose, dextran, dulcitol, fumaric acid, inulin, lactose, D-maltose, D-melibiose, melezitose, D-raffinose, L-rhamnose, D-sorbose, sucrose, succinic acid, thioglycollate, D-xylose, L-aspartic acid, L-aspargine, L-cysteine, L-glycine, L-histidine, Lleucine, L-isoleucine, L-methionine, L-proline, L-threonine or L-valine. Sensitive to the antibiotics ampicillin, amoxycillin, bacitracin, carbenicillin, chloramphenicol, chlortetracycline, colistin, cotrimoxazole, erythromycin, kanamycin, gentamicin, lincomycin, nitrofurazone, nitrofurantoin, nystatin, oxytetracyclin, penicillin, polymyxin B, rifampicin, tetracycline and tobramycin, but resistant to furazolidone, furoxone and trimethoprim. DNA G+C content is $60 \cdot 7 \mathrm{~mol} \%$.

The type strain is CMS $35^{\mathrm{T}}\left(=\right.$ MTCC $4992^{\mathrm{T}}=\mathrm{DSM}$ $\left.15318^{\mathrm{T}}\right)$.

\section{Description of Pseudomonas meridiana sp. nov.}

Pseudomonas meridiana (me.ri.di.a'na. L. fem. adj. meridiana of or belonging to the south or south side, southern, southerly, meridional; pertaining to the South Pole).

Forms circular, convex, smooth and translucent colonies with a diameter of 1-2 mm. Cells are Gram-negative, motile with a polar flagellum, rod-shaped and psychrophilic (grow at $\left.4-30{ }^{\circ} \mathrm{C}\right)$, can tolerate $3 \% \mathrm{NaCl}(\mathrm{w} / \mathrm{v})$ and grow at an optimum $\mathrm{pH}$ of 7 . Positive for catalase, oxidase and lipase and weakly positive for urease; reduces nitrate to nitrite; negative for phosphatase, $\beta$-galactosidase, gelatinase, arginine dihydrolase, arginine decarboxylase, lysine decarboxylase, indole production, methyl red and Voges-Proskauer test. Does not hydrolyse aesculin, starch or cellulose. Acid is produced from $\mathrm{D}$-fructose, D-galactose, D-glucose, D-mannose and D-mannitol, but not from L-arabinose, lactose, L-rhamnose, sucrose or D-xylose. Utilizes acetate, adonitol, citrate, meso-erythritol, D-fructose, D-galactose, D-glucose, L-arabinose, glycerol, meso-inositol, lactic acid, D-mannose, D-mannitol, pyruvate, D-ribose, sorbitol, trehalose, L-alanine, L-arginine, L-glutamic acid, Lglutamine, L-lysine, L-serine, L-tyrosine and L-tryptophan as sole carbon sources, but not D-cellobiose, cellulose, dextran, dulcitol, fumaric acid, inulin, lactose, D-maltose, Dmelibiose, melezitose, D-raffinose, L-rhamnose, D-sorbose, sucrose, succinic acid, thioglycollate, D-xylose, L-aspartic acid, L-aspargine, L-cysteine, L-glycine, L-histidine, Lleucine, L-isoleucine, L-methionine, L-proline, L-threonine 
or L-valine. Resistant to ampicillin, amoxycillin, bacitracin, carbenicillin, chloramphenicol, colistin, cotrimoxazole, erythromycin, furazolidone, furoxone, gentamicin, lincomycin, nitrofurantoin, nystatin, penicillin, polymyxin $B$ and trimethoprim, but sensitive to chlortetracycline, kanamycin, nitrofurazone, oxytetracycline, rifampicin, tetracycline and tobramycin. DNA G $+\mathrm{C}$ content is $63 \cdot 2 \mathrm{~mol} \%$.

The type strain is CMS $38^{\mathrm{T}}\left(=\right.$ MTCC $4993^{\mathrm{T}}=\mathrm{DSM}$ $\left.15319^{\mathrm{T}}\right)$.

\section{Description of Pseudomonas proteolytica sp. nov.}

Pseudomonas proteolytica (pro.te.o.ly'ti.ca. N.L. fem. adj. proteolytica proteolytic).

Forms circular, convex, smooth and translucent colonies with a diameter of 1-2 mm. Cells are Gram-negative, motile with a polar flagellum, rod-shaped and psychrophilic (grow at $4-30{ }^{\circ} \mathrm{C}$ ), can tolerate $3 \% \mathrm{NaCl}(\mathrm{w} / \mathrm{v})$ and grow at an optimum $\mathrm{pH}$ of 7 . Positive for catalase, oxidase, lipase and gelatinase; reduces nitrate to nitrite; negative for phosphatase, urease, $\beta$-galactosidase, arginine dihydrolase, arginine decarboxylase, lysine decarboxylase, indole production, methyl red and Voges-Proskauer test. Does not hydrolyse aesculin, starch or cellulose. Acid is produced from D-fructose, D-galactose, D-glucose, D-mannose and Dmannitol, but not from L-arabinose, lactose, L-rhamnose, sucrose or D-xylose. Utilizes acetate, adonitol, citrate, mesoerythritol, D-fructose, D-galactose, D-glucose, glycerol, meso-inositol, lactic acid, D-mannose, D-mannitol, pyruvate, $\mathrm{D}$-ribose, sorbitol, trehalose, $\mathrm{L}$-alanine, $\mathrm{L}$-arginine, $\mathrm{L}$ glutamic acid, L-glutamine, L-lysine, L-serine, L-methionine, L-phenylalanine, L-tyrosine and L-tryptophan as sole carbon sources, but not D-cellobiose, cellulose, dextran, dulcitol, fumaric acid, inulin, lactose, D-maltose, Dmelibiose, melezitose, D-raffinose, L-rhamnose, D-sorbose, sucrose, succinic acid, thioglycollate, D-xylose, L-aspartic acid, L-aspargine, L-cysteine, L-glycine, L-histidine, L-leucine, L-isoleucine, L-proline, L-threonine or L-valine. Resistant to ampicillin, amoxycillin, bacitracin, carbenicillin, chloramphenicol, cotrimoxazole, erythromycin, furazolidone, furoxone, lincomycin, nitrofurazone, nitrofurantoin, nystatin, penicillin and trimethoprim, but sensitive to chlortetracycline, colistin, gentamicin, kanamycin, oxytetracycline, polymyxin $\mathrm{B}$, rifampicin, tetracycline and tobramycin. DNA G $+\mathrm{C}$ content is $58 \cdot 3 \mathrm{~mol} \%$.

The type strain is CMS $64^{\mathrm{T}}\left(=\mathrm{MTCC} 4994^{\mathrm{T}}=\mathrm{DSM}\right.$ $\left.15321^{\mathrm{T}}\right)$.

\section{Acknowledgements}

This work was supported by a grant from the Department of Biotechnology, Government of India, New Delhi, India. The riboprinting work was carried out at DSMZ, Germany, through the UNESCO-IUMS-MIRCENS-SGM short-term fellowship awarded to G.S.N.R. by the International Union of Microbiological Societies (IUMS).

\section{References}

Anzai, Y., Kim, H., Park, J. Y., Wakabayashi, H. \& Oyaizu, H. (2000). Phylogenetic affiliation of the pseudomonads based on 16S rRNA sequence. Int J Syst Evol Microbiol 50, 1563-1589.

Baïda, N., Yazourh, A., Singer, E. \& Izard, D. (2001). Pseudomonas brenneri sp. nov., a new species isolated from natural mineral waters. Res Microbiol 152, 493-502.

Bradbury, J. F. (1987). Pseudomonas tolaasi. In CMI Descriptions of Pathogenic Fungi and Bacteria, no. 894. Kew, UK: CAB International Mycological Institute.

Bruni, V., Gugliandolo, C., Maugeri, T. \& Allegra, A. (1999). Psychrotrophic bacteria from a coastal station in the Ross sea (Terra Nova Bay, Antarctica). New Microbiol 22, 357-363.

Coroler, L., Elomari, M., Hoste, B., Gillis, M., Izard, D. \& Leclerc, H. (1996). Pseudomonas rhodesiae sp. nov., a new species isolated from natural mineral waters. Syst Appl Microbiol 19, 600-607.

Dabboussi, F., Hamze, M., Elomari, M., Verhille, S., Baida, N., Izard, D. \& Leclerc, H. (1999). Taxonomic study of bacteria isolated from Lebanese spring waters: proposal for Pseudomonas cedrella sp. nov. and P. orientalis sp. nov. Res Microbiol 150, 303-316.

De Ley, J. (1992). The Proteobacteria: ribosomal RNA cistron similarities and bacterial taxonomy. In The Prokaryotes, 2nd edn, pp. 2111-2140. Edited by A. Balows, H. G. Trüper, M. Dworkin, W. Harder \& K.-H. Schleifer. New York: Springer.

Elomari, M., Coroler, L., Hoste, B., Gillis, M., Izard, D. \& Leclerc, H. (1996). DNA relatedness among Pseudomonas strains isolated from natural mineral waters and proposal of Pseudomonas veronii sp. nov. Int J Syst Bacteriol 46, 1138-1144.

Felsenstein, J. (1993). PHYLIP (phylogeny inference package), version 3.5c. Department of Genetics, University of Washington, Seattle, USA.

Higgins, D. G., Bleasby, A. T. \& Fuchs, R. (1992). CLUSTAL V: improved software for multiple sequence alignment. Comput Appl Biosci 8, 189-191.

Holding, A. J. \& Collee, J. G. (1971). Routine biochemical tests. Methods Microbiol 6A, 2-32.

Hugh, R. \& Leifson, E. (1953). The taxonomic significance of fermentative versus oxidative metabolism of carbohydrates by various gram-negative bacteria. J Bacteriol 66, 24-26.

Ivanova, E. P., Gorshkova, N. M., Sawabe, T. \& 8 other authors (2002). Pseudomonas extremorientalis sp. nov., isolated from a drinking water reservoir. Int J Syst Evol Microbiol 52, 2113-2120.

Kimura, M. (1980). A simple method for estimating evolutionary rates of base substitutions through comparative studies of nucleotide sequences. J Mol Evol 16, 111-120.

Kriss, A. E., Mitskevich, I. N., Rozanova, E. P. \& Osnitskaia, L. K. (1976). Microbiological studies of the Wanda Lake (Antarctica). Mikrobiologiya 45, 1075-1081 (in Russian).

Laemmli, U. K. (1970). Cleavage of structural proteins during the assembly of the head of bacteriophage T4. Nature 227, 680-685.

Lane, D. J. (1991). 16S/23S rRNA sequencing. In Nucleic Acid Techniques in Bacterial Systematics, pp. 115-175. Edited by E. Stackebrandt \& M. Goodfellow. Chichester: Wiley.

Maugeri, T. L., Gugliandolo, C. \& Bruni, V. (1996). Heterotrophic bacteria in the Ross Sea (Terra Nova Bay, Antarctica). New Microbiol 19, 67-76.

Migula, W. (1984). Über ein neues System der Bakterien. Arb Bakteriol Inst Karlsruhe 1, 235-238 (in German).

Moore, E. R. B., Mau, M., Arnscheidt, A., Böttger, E. C., Hutson, R. A., Collins, M. D., Van De Peer, Y., De Wachter, R. \& Timmis, K. N. 
(1996). The determination and comparison of the 16S rRNA gene sequences of species of the genus Pseudomonas (sensu stricto) and estimation of the natural intrageneric relationships. Syst Appl Microbiol 19, 478-492.

Munsch, P., Alatossava, T., Marttinen, N., Meyer, J.-M., Christen, R. \& Gardan, L. (2002). Pseudomonas costantinii sp. nov., another causal agent of brown blotch disease, isolated from cultivated mushroom sporophores in Finland. Int J Syst Evol Microbiol 52, 1973-1983.

Palleroni, N. J., Kunisawa, R., Contopolou, R. \& Doudoroff, M. (1973). Nucleic acid homologies in the genus Pseudomonas. Int J Syst Bacteriol 23, 333-339.

Reddy, G. S. N., Aggarwal, R. K., Matsumoto, G. I. \& Shivaji, S. (2000). Arthrobacter flavus sp. nov., a psychrophilic bacterium isolated from a pond in McMurdo Dry Valley, Antarctica. Int J Syst Evol Microbiol 50, 1553-1561.

Reddy, G. S. N., Prakash, J. S. S., Matsumoto, G. I., Stackebrandt, E. \& Shivaji, S. (2002). Arthrobacter roseus sp. nov., a psychrophilic bacterium isolated from an Antarctic cyanobacterial mat sample. Int J Syst Evol Microbiol 52, 1017-1021.

Reddy, G. S. N., Prakash, J. S. S., Prabahar, V., Matsumoto, G. I., Stackebrandt, E. \& Shivaji, S. (2003). Kocuria polaris sp. nov., an orange-pigmented psychrophilic bacterium isolated from an Antarctic cyanobacterial mat sample. Int J Syst Evol Microbiol 53, 183-187.

Sato, N. \& Murata, N. (1988). Membrane lipids. Methods Enzymol 167, 251-259.

Shinde, P. A. \& Lukezic, F. L. (1974). Isolation, pathogenicity and characterization of fluorescent pseudomonads associated with discoloured alfalfa roots. Phytopathology 64, 865-871.
Shivaji, S., Rao, N. S., Saisree, L., Sheth, V., Reddy, G. S. N. \& Bhargava, P. M. (1989a). Isolation and identification of Pseudomonas spp. from Schirmacher Oasis, Antarctica. Appl Environ Microbiol 55, 767-770.

Shivaji, S., Rao, N. S., Saisree, L., Reddy, G. S. N., Seshu Kumar, G. \& Bhargava, P. M. (1989b). Isolates of Arthrobacter from the soils of Schirmacher Oasis, Antarctica. Polar Biol 10, 225-229.

Shivaji, S., Ray, M. K., Rao, N. S., Saisree, L., Jagannadham, M. V., Seshu Kumar, G., Reddy, G. S. N. \& Bhargava, P. M. (1992). Sphingobacterium antarcticus sp. nov., a psychrotrophic bacterium from the soils of Schirmacher Oasis, Antarctica. Int J Syst Bacteriol 42, 102-106.

Shivaji, S., Vijaya Bhanu, N. \& Aggarwal, R. K. (2000). Identification of Yersinia pestis as the causative organism of plague in India as determined by $16 \mathrm{~S}$ rDNA sequencing and RAPD-based genomic fingerprinting. FEMS Microbiol Lett 189, 247-252.

Stanier, R. Y., Palleroni, N. J. \& Doudoroff, M. (1966). The aerobic pseudomonads: a taxonomic study. J Gen Microbiol 43, 159-271.

Stolp, H. \& Gadkari, D. (1981). Nonpathogenic members of the genus Pseudomonas. In The Prokaryotes, vol. 1, pp. 719-741. Edited by M. P. Starr, H. Stolp, H. G. Trüper, A. Balows \& H. G. Schlegel. Berlin: Springer.

Tourova, T. P. \& Antonov, A. S. (1987). Identification of microorganisms by rapid DNA-DNA hybridisation. Methods Microbiol 19, 333-355.

Verhille, S., Baïda, N., Dabboussi, F., Hamze, M., Izard, D. \& Leclerc, H. (1999). Pseudomonas gessardii sp. nov. and Pseudomonas migulae sp. nov., two new species isolated from natural mineral waters. Int J Syst Bacteriol 49, 1559-1572. 